\title{
公共施設と都市公園の隣接事例にみるマネジメントと空間の在り方に関する考察 \\ Management and Public Space Concepts in the Case of Adjacent Public Facilities and Urban Parks
}

\author{
湯淺 かさね* 池邊このみ*
}

\author{
Kasane YUASA Konomi IKEBE
}

\begin{abstract}
This paper focuses on Musashino Place and Kyonan-Fureai-Hiroba Park in Musashino City, Tokyo, Japan. The place and park provide examples of integrated maintenance and management methods at facilities and parks that are adjacent to one another. The objective of this research is to examine the characteristic ways in which various actors are involved in management that is aimed at the utilization of public facilities with adjacent urban parks. This study also discusses the ways in which those spaces are practically used. We consider the main points of this management type to be the following: (1) Clearly positioning cooperation in the planning stage, (2) Ensuring the compatibility of the area's events and maintenance schedule, (3) Properly utilizing indoor and outdoor spatial characteristics, (4) Collaborating the activities of public and private actors in daily, (5) Implementing events that contribute to proper management.
\end{abstract}

Keywords: exterior space, facility management(FM), effective use, public-private partnership, Musashino Place キーワード：屋外空間, ファシリティマネジメント $(\mathrm{FM})$, 活用, 官民連携, 武蔵野プレイス

\section{1.はじめに}

\section{(1) 背景と目的}

現代日本の公共施設や都市公園等のインフラについては，一斉 老朽化や税収減による整備・維持管理に係る財源不足等の課題が 顕在化し，ストック活用の重要性が高まっている。近年は特に都 市公園・道路・河川等の屋外の公共空間がストック活用の対象と して着目される中，都市公園については，それ自体が緑の公共空 間としての機能を果たすだけでなく，隣接する河川や道路，公共 施設等と連携して一帯に良好な都市空間を形成すると共に，市民 や民間事業者等との連携・協働によるマネジメントを強化し都市 公園のストックを一層利活用していくことが求められている 1)。 都市公園と様々な施設との連携方策としては，1. 都市公園の中 に施設を設置，2. 都市公園に隣接する施設との一体的な利用を 想定した公園整備，3. 隣接する施設との一体的な整備・管理運 営の実施等の方法がある 2)。一方，多くの公共施設の屋外空間は 建築と囲障との間の「外構」とされ積極的に利活用されない傾向 にあり, 膨大な空間ストックがあるものの, 都市の公共空間とし て賑わい，交流，憩等の機能に乏しいものが少なくない。

本研究では多主体と連携したマネジメント強化により都市公園 と公共施設のストック効果を高めるという観点からこれらの隣接 事例に着目し，計画から運用段階までのマネジメントの実態を明 らかにすると共に，利活用を促進するマネジメントの特徴及びそ れを実践する空間の在り方について考察することを目的とする。

\section{(2) 研究の対象}

本研究で対象とする「武蔵野市立 ひと・まち・情報創造館 武 蔵野プレイス (以下, 武蔵野プレイスと記載)」及び隣接する「武 蔵野市立境南ふれあい広場公園 (以下, 公園と記載)」は, 都市公 園と様々な施設との連携方策の中でも，近年着目されている前述 の「3. 隣接する施設との一体的な整備・管理運営の実施」の事 例 2)である。武蔵野プレイス (敷地面積 $2166.20 \mathrm{~m}^{2}$ ，延床面積 $9809.76 \mathrm{~m}^{2}$ ，地上 4 階地下 3 階 $)$ 及び公園 $\left(2162.10 \mathrm{~m}^{2}\right)$ は JR
武蔵境駅の南口に面し，農水省の食料倉庫跡地に武蔵野市の市街 地活性化事業として計画され，2011 年 1 月に竣工，7月にオープ ンした。武蔵野プレイスは, 2011 年度末に閉館した武蔵野市立西 武図書館を引き継いだ図書館機能に加え生涯学習支援, 市民活動 支援，青少年活動支援の機能とカフェを併せ持った施設である。 一方の公園は武蔵野市唯一の駅前商業地域に整備された公園であ り, 周囲にはフェンス等は無く沿道や武蔵境駅ビルの歩行空間と 連続性のある空間となっている。多くの既存樹木を活かした中高 木が緑陰を形成し多数のベンチが配置されている。また, 公園中 央部には様々なイベントで活用できる芝生広場が設けられている。 (3) 方法

文献調査 ${ }^{32}$ 13)及び聞き取り調査, 質問紙調査, 観察調査を行い (表一1),（1）対象地及び周辺地域の計画段階から現在までの変 遷過程を整理し, 武蔵野プレイスと公園の連携に関する状況を把 握し，周辺地域にもたらした影響を明らかにする (第 2 章)。(2) マネジメントにおける官民の組織の活動内容と空間の利活用状況 を整理し, 連携に関する特徴と課題を把握する (第 3 章・第 4 章)。

本研究において「マネジメント」の用語は既往の研究 14)を参考 に, 研究対象の計画・設計段階から整備実施及び現在の維持管理・ 活用に関する主体の組織的取組みを示し，「連携」の用語は研究対 象に関わる主体がその活動において他の主体と情報を共有し協力 してマネジメントを進めることを示す概念として使用する。

\section{(4) 既往研究}

公共空間のマネジメントにおける官民多主体の連携の側面に関 しては，歩行者専用道路のマネジメントや利活用について長期間 にわたる変遷を整理した研究 14)15)，大学と地域の連携による地域 まちづくり主体の活動を分析した研究 ${ }^{16)}$, 大学キャンパスと公園 の一体的整備に関する研究 17)がある。また公共施設及び公園につ いては近年のストック活用の流れを受け, 自治体におけるファシ リティマネジメント (FM) の重要性が高まり, 主に公共施設の 再編・再整備に関する研究 18)や, 利活用に関する研究 19)がなされ

*千葉大学大学院園芸学研究科 
表-1 研究方法

\begin{tabular}{|c|c|c|c|}
\hline 方法 & 調査時期 & & 対象 \\
\hline \multirow{9}{*}{$\begin{array}{l}\text { 聞取 } \\
\text { 調査 }\end{array}$} & 2015.6 .11 & \multicolumn{2}{|c|}{ (公財) 武蔵野生涯学習振興事羓目団 } \\
\hline & 2015.7 .24 & \multicolumn{2}{|c|}{ 武蔵野市環境部緑のまち推進課 } \\
\hline & 2015.7 .24 & \multicolumn{2}{|c|}{ 武蔵野市財務部施設課 } \\
\hline & 2015.8 .4 & \multicolumn{2}{|c|}{ (公財) 武蔵野生涯学習振興事業団 } \\
\hline & $2016.10,7$ & \multicolumn{2}{|c|}{ (公財) 武蔵野生涯学習振興事業団 } \\
\hline & 2017.6 .8 & \multicolumn{2}{|c|}{ 武蔵境活性化委員会 } \\
\hline & 2017.6 .21 & \multicolumn{2}{|c|}{ 武蔵野市環境部緑のまち推進課 } \\
\hline & 2017.8 .24 & \multirow{2}{*}{\multicolumn{2}{|c|}{$\begin{array}{l}\text { さかいマルシェ出店者 } \\
\text { (公財) 武蔵野生涯学習振興事業団 }\end{array}$}} \\
\hline & 2017.9 .7 & & \\
\hline $\begin{array}{l}\text { 質問紙 } \\
\text { 調查 }\end{array}$ & 2016. 8. 25 & \multicolumn{2}{|c|}{ (株)JR中央ラインモール＼cjkstart業務推進本部 } \\
\hline 方法 & 調査日 & 時間 & イベント名 \\
\hline \multirow{16}{*}{$\begin{array}{l}\text { 観察 } \\
\text { 調査 }\end{array}$} & 2014.12.7 & $16: 00-17: 30$ & なし (平常利用) \\
\hline & 2015.6 .7 & $11: 00-19: 00$ & なし (平常利用) \\
\hline & 2015.6 .11 & $14: 30-17: 30$ & なし (平常利用) \\
\hline & 2015.7 .19 & $15: 00-18: 00$ & なし (平常利用) \\
\hline & 2016.10 .10 & $15: 00-16: 30$ & 青空おはなし会 (絵本読み聞かせイベント) \\
\hline & 2016.10 .13 & $15: 00-16: 00$ & なし (平常利用) \\
\hline & 2016.12 .11 & $17: 00-19: 30$ & 大人のための天文学入門講座 \\
\hline & 2017.6 .8 & $11: 00-17: 00$ & なし (平常利用) \\
\hline & 2017.6 .9 & $11: 30-15: 30$ & なし (平常利用) \\
\hline & 2017.6 .17 & $11: 00-12: 00$ & 芝生植付けイベント”芝生を元気に！” \\
\hline & 2017.6 .27 & $15: 30-17: 00$ & なし (平常利用) \\
\hline & 2017.7 .16 & $10: 30-12: 00$ & さかいマルシェ \\
\hline & 2017.7 .29 & $15: 00-16: 30$ & 青少年サマーライブ \\
\hline & 2017.8 .9 & $13: 00-18: 00$ & 境南盆踊り \\
\hline & 2017.8 .19 & $17: 00-17: 30$ & さかい夜市2017 \\
\hline & 2017.8 .24 & $15: 00-17: 00$ & なし (平常利用) \\
\hline
\end{tabular}

ている。しかし自治体所有の公共施設と土地やインフラのマネジ メントにおける連携について論じた研究は殆どみられず，それら を自治体の資産として総合的な視点でマネジメントを行う必要性 について論じた研究 20)があるが，具体的な事例の分析を通したマ ネジメントにおける連携方法等に関する研究の蓄積は薄い。美術
館や図書館，体育館等の公共施設が公園の中や隣接地に立地する 事例は多いが, 障壁の存在や建物バックヤードの位置等, 景観面・ 利用面共に問題があるにも関わらず, 公共施設と公園を対象とし, マネジメントの連携について論じた研究は殆どみられない。

武蔵野プレイスについては，まちの活性化の観点から論じた文 献 21)，利用行動の観点から施設機能を類型化した研究 22)がある。 マネジメントの観点からは指定管理者による管理運営に関して論 じた文献 23)24)があるが，いずれも隣接する公園に関する記述は薄 く武蔵野プレイスと公園の関係や連携に関寸る研究はみられない

本研究はこれまで行政が縦割りの組織体制により計画・整備・ 運用してきた公共施設及び公園とは異なり，多主体の連携でマネ ジメントされてきた事例に着目し変遷と現状を明らかにする点で, 既往の研究を発展させる独自性を有すると共に, 公共施設と公園 について公共空間としての利活用を志向するマネジメントに関す る考察を行う研究として意義を持つものと位置づけられる。

\section{2. 周辺地域の変遷と武蔵野プレイス及び公園の事業経過}

武蔵境地域における都市整備の概要・変遷と, 武蔵野プレイス と公園の事業経過を整理した（表一 2 ，表一 3 ，図-1)。事業経 過は条件整理期と計画・設計期，整備期，運用期に分けられる。

（1）周辺地域の変遷における多主体の関わりと現況

武蔵野プレイスと公園の他にも都市再生整備計画等により鉄道 連続立体交差化に合わせた都市基盤整備が行われ，主に JR グル 一プと武蔵野市，まちづくり関連団体との連携が寄与している。 武蔵境地域は武蔵境駅の南北が線路により分断され，南北方向の

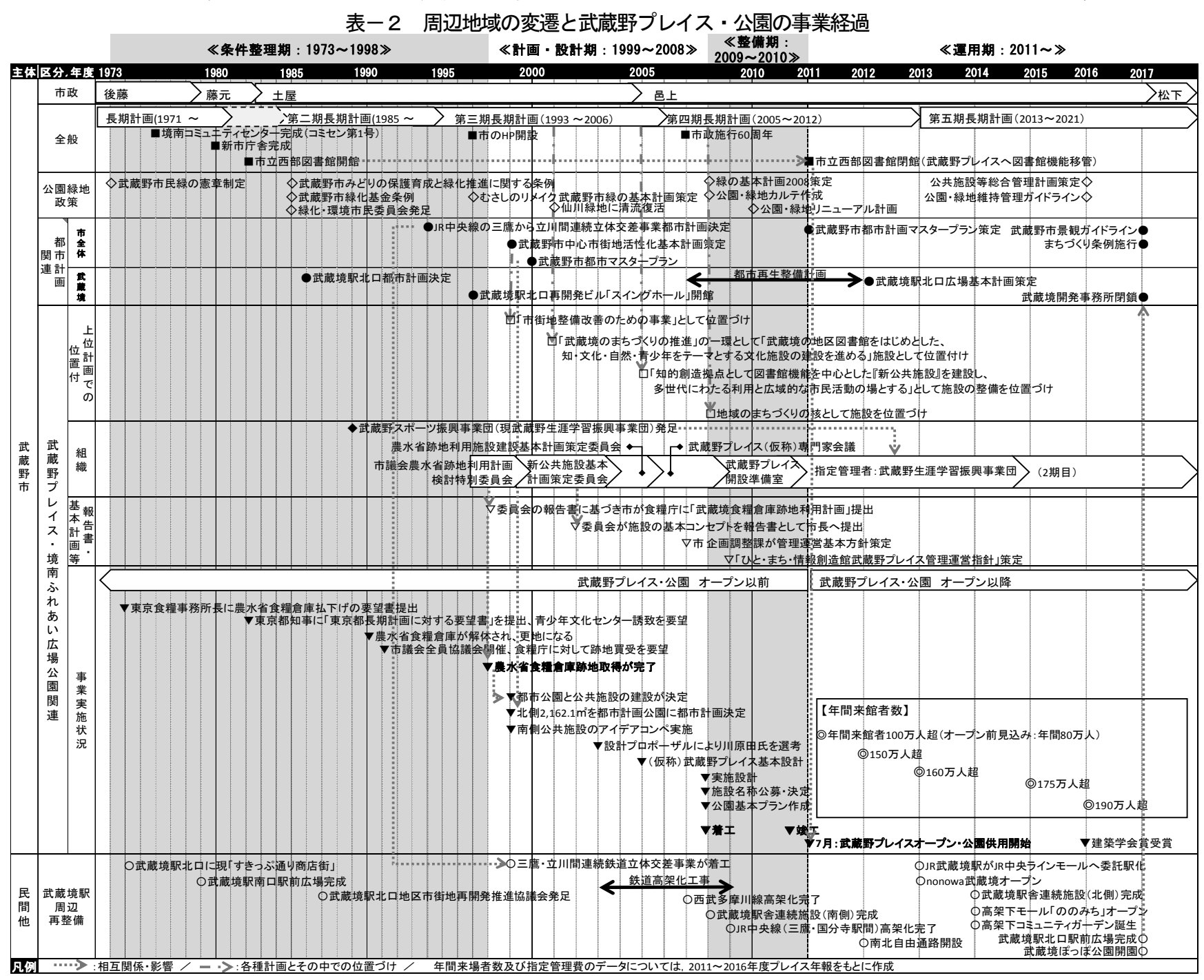


人の移動は制限されていたが, 2009 年鉄道高架化完了によりその 分断が解消され，その 2 年後に武蔵野プレイス及び公園がオープ ンした。施設規模の見直し 27 等により計画開始以来オープンまで 38 年間を要したが, 鉄道高架化による南北分断解消後にオープン したことで，鉄道利用で訪れる周辺地域からの利用者は元より， 武蔵境地域南北の住民が平等に利用できる施設となった ${ }^{28)}$

鉄道高架化と合わせ武蔵野市では南北駅前広場の整備が行われ 駅と駅前広場一体の「地域の顔」づくりに取り組んだ。高架化完 了後にはJR 東日本による高架下活用事業として商業施設等によ るモール「ののみち」及び高架下の歩行空間の整備が進められた。 高架下活用事業のコンセプトは「街の回遊や交流を促進する」こ とであり，その対応として武蔵野市による歩道（市道）と JR 東 日本による高架下歩道を一体的に整備し歩行空間を確保したこと, 地域の自生植物によるコミュニティガーデンを設け住民参加の植 替えワークショップを行えるようにしたこと，地域の名所や歴史 を紹介寸るサイン等を設置していることが確認された ${ }^{29)}$ 。なお高 架下には新たに JR グループ整備の「覟いの広場」約 $350 \mathrm{~m}^{2}$ と武

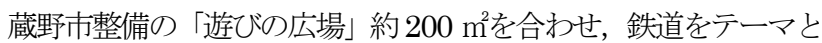
した都市公園「ぽっぽ公園」が整備され，2017年 4 月に供用開 始された。JR グループと市の連携の体制が継続しているといえ る30)。また，JRグループにおいては後述の武蔵境活性化委員会 （以下，活性化委員会と記載）や武蔵境駅舎広場街づくり協議会 に参加し，周辺地域の住民及び事業者と高架化事業を始め高架化 後の開発の将来計画において周辺地域との連携が図られている。 JR グループと武蔵野プレイス・公園のマネジメントとの連携に ついは公園を会場として JR グループ主催のイベントを開催す る,イベントチラシを武蔵野プレイスに配架する等が確認された。

また，武蔵野プレイス・公園オープンの翌年に市が実施した来 街者調査 31 によると，ほぼ半数が直近の 2 年間で武蔵境を訪れる 機会が増えたと回答しており，武蔵境での利用施設では，大手流 通系百貨店 $(46.4 \%)$ に次いで武蔵野プレイス $(32.0 \%)$ が 2 番 目に多く，平日昼間だけを見れば武蔵野プレイス（51.5\%）が百 貨店 $(50.3 \%)$ を上回っている。

\section{（2）計画 · 設計期における施設と公園の連携の位置づけ}

武蔵野プレイス及び公園の計画段階の基本計画等により，両施 設の連携に関する事項を把握した（表一3）。結果，武蔵野プレイ スと公園の連携に関する内容 (13 件) だけでなく, それらとまち との関わりについての記述も多く見られた（12 件)。また，複数 の記載に共通していた利活用に関する表現を分類したところ, 「緑」「一体的整備」「一体的利用」「一体的管理」「人が集まる・ 交流・にぎわい等」「街のシンボル」「まちづくり」が多くみられ た。但し「一体的」という語については，その前後の文脈によっ て「整備」「利用」「管理」のいずれに関わる内容かを読夕解き， 分類した。最も多い記述は「一体的利用 (16 件)」であり，「カフ エを公園側のテラスに延長」「イベント時に建物と公園を一体的 に利用」「建物内部のラウンジと連続する緑陰読書スペース」等の 文章に加え概念図やパースで具体的なイメージが記載されている。

\section{3．官民多主体によるマネジメントの取り組み}

\section{(1) 組織体制及び各主体の関係}

武蔵野プレイス及び公園の管理運営や利活用促進等, マネジメ ントに関与している主体間の関係について図-2に示す。

（2）市行政と指定管理者によるマネジメント

武蔵野プレイスにおける管理運営体制の特徴として, 従来の複合 施設のように施設内の機能毎に市の所管課がつくのではなく，武 蔵野市教育委員会生涯学習スポーツ課（以下，生涯学習スポーツ 課と記載) が一括所管する複合機能施設である点が挙げられる。 公園部分については, 生涯学習スポーツ課に技術職の職員がいな

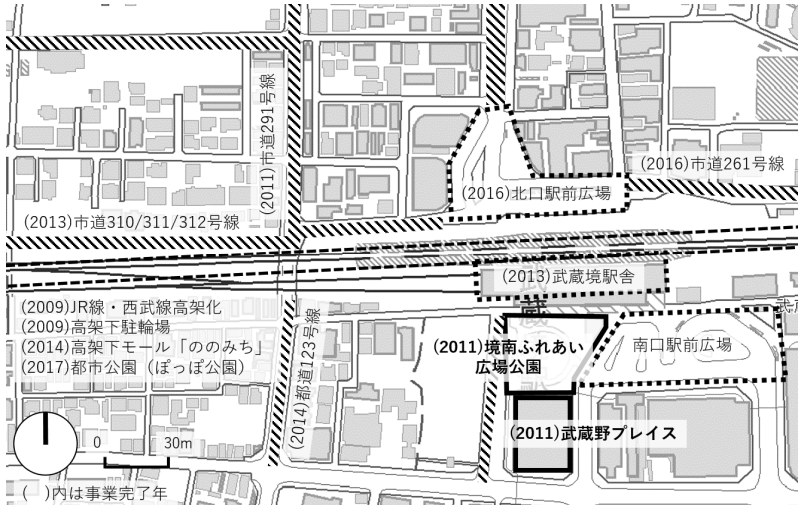

図-1 武蔵境地域の主な都市整備事業 25)26)

表一3 基本計画等による武蔵野プレイスと公園の連携の位置付
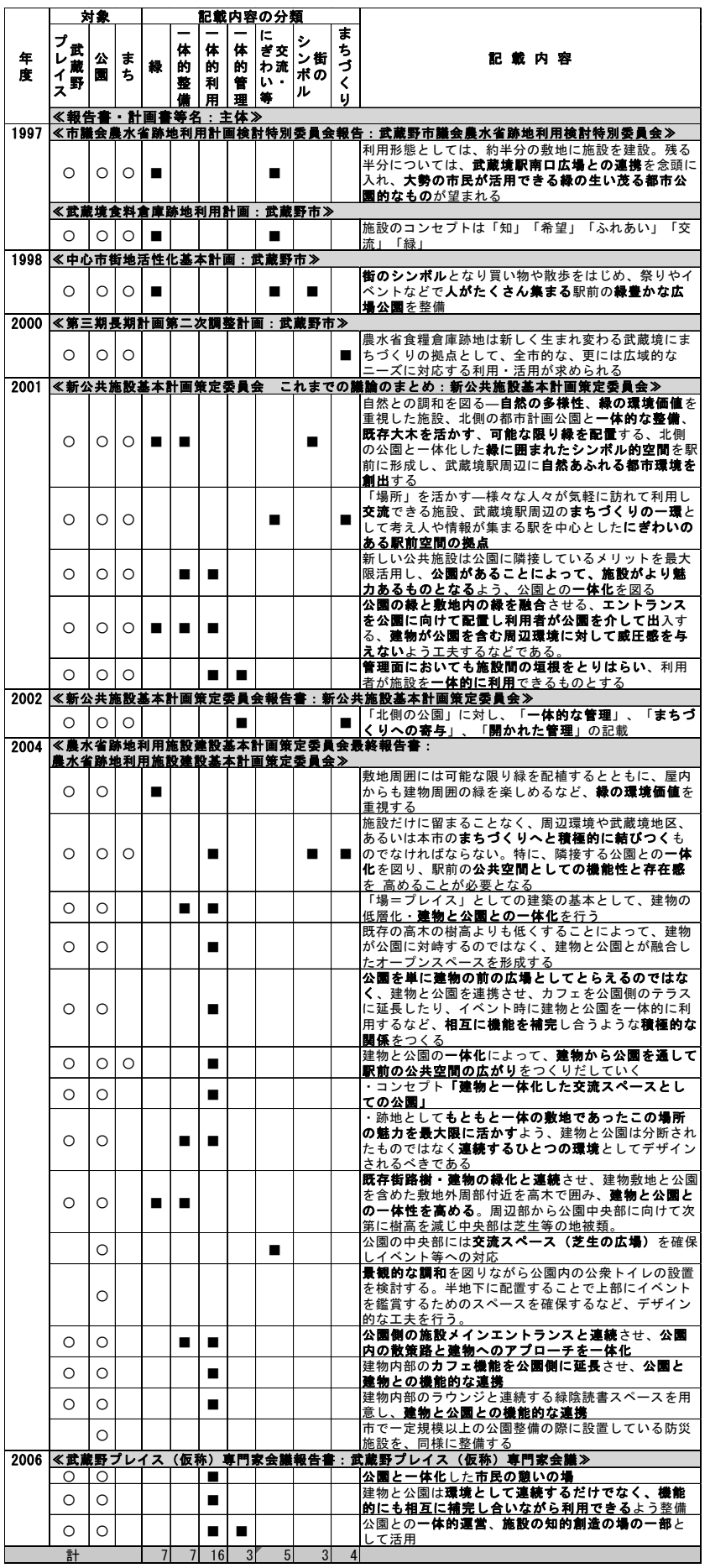


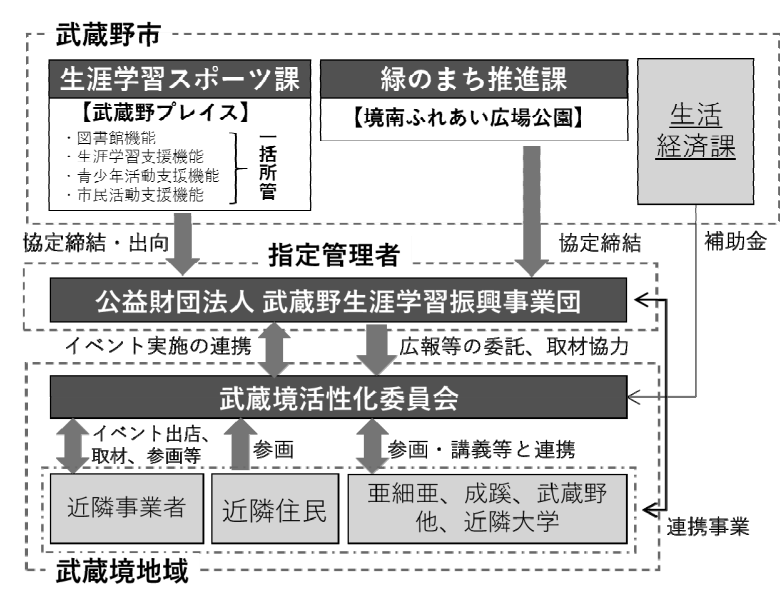

図ー2 マネジメント関連主体相互の関係

いため緑のまち推進課が所管している。なお，武蔵野プレイス及 び公園は，市の政策の推進に向けて市と指定管理者が密接な連携 を図りながら施設の管理運営を行うことが求められる施設 32 ) して非公募で選定された公益財団法人武蔵野生涯学習振興事業団 (以下，指定管理者と記載）がオープン時より継続して管理運営 を行っており, 武蔵野プレイス部分は生涯学習スポーツ課, 公園 部分は緑のまち推進課がそれぞれ指定管理者と協定を結んでいる。 常駐する職員は管理係，生涯学習支援係，図書館係に分かれ，施 設全般の管理運営については主に管理係が担当している。管理係 は 2016 年現在 4 名である。開館時間が午前 9 時 30 分から午後 10 時までと長いため職員はシフト制をとっており, 武蔵野プレイ スと公園で担当を分けず管理係の全員が双方の管理を担うことで, 武蔵野プレイスと公園は管理運営の規定上は別の施設であるが現 場職員の意識では一体のものと捉えていることが確認された ${ }^{33)}$ 。 なお，公園の緑の維持管理における技術的側面については指定管 理者の職員には緑に関する専門の技術者がおらず，所管課である 緑のまち推進課の主導により行われる場面もあり，指定管理者側 の技術向上の方策が求められていることが把握された ${ }^{34)}$

\section{（3）指定管理者と周辺地域民間組織間の連携}

武蔵野プレイスでは年間を通して大学や市民団体，企業及ひ研 究機関等の様々な地域主体との連携事業が行われ，その件数は毎 年 20 件以上，参加者数は 4,500〜7,000 名程度で推移しており, 最も多かった 2015 年には 30 件・参加者数 11,107 名にのぼる ${ }^{13)}$ 。 これらの連携事業は主に武蔵野プレイス内で行われているが，内 容によって地域の企業を会場として実施されることもある。

周辺地域で活動する組織として, 活性化委員会の果たす役割も 大きい。活性化委員会は 2009 年に発足し武蔵境地域の事業者及 び住民, 大学職員, 学生等が構成員となっているまちづくり団体 である。武蔵野プレイス及び公園の利活用においてはこの活性化 委員会の活動を核とした指定管理者との連携体制が構築されてい る。活性化委員会の多様な活動のうちの一つとして地元の情報を 掲載するフリーペーパー35)を発行しており，その紙面には武蔵野 プレイス関連の記事が 2017 年春号 (Vol.21) までの期間に累計 12 回掲載されている。このフリーペーパーは武蔵野プレイス館内 にも配架されており，フリーペーパーそのものと活性化委員会の 認知度向上にもつながっている。また，活性化委員会としては武 蔵野プレイス及び公園を会場としたイベントを 2012 年から継続 して実施していること, 武蔵野プレイスにて行われる指定管理者 主催イベントの広報も受託していることが確認された。単発的な イベントのみではなく定常的な関わりがあること，関わり方が活 性化委員会から指定管理者への公園使用許可の申請, 取材協力依 頼，配架依頼等だけでなく，指定管理者から活性化委員会への業
務委託，武蔵野プレイス及び公園の広報といった双方向の連携・ 協力が行われていることが把握できた。

また，指定管理者と活性化委員会という組織間の連携だけでな く, 活性化委員会主催のイベントには地元事業者が毎回参加し, 中には 2012 年当時から現在まで継続して参加をしている事業者 もおり，イベント参加を通して事業者と地元住民や地主との関係 構築につながっている。事業者側においては，ここで構築された 関係を活かし，新たなことを武蔵境地域で行いたいというモチべ ーションの醸成にも寄与していることが分かった。

\section{4. 公共空間としての利活用の状況}

対象地における空間利活用の特徵について，観察調査や聞き取 り調査，武蔵野プレイス公式 HP 等の公開情報から整理した。

\section{（1）イベントの種類と実施主体}

2011 年のオープンから実施主体別のイベント件数推移を図-3 に，イベント内容推移を図-4 に示寸。指定管理者主催のイベン トとしては，青空ふれあいおはなし会，天体教室等がある。特に 天体教室については武蔵野プレイスの屋内で天体に関する講座を 行い, その後公園へ出て実際に天体観測をするといった，屋内と 屋外を一体的・相互補完的に利用しているものである。屋内外の 一体的利用については第 2 章で把握した各文献で多く言及されて おり，その内容を踏まえて空間特性を活か寸ことに対して積極的 に取り組むという指定管理者の意識が聞き取り調査 28$)$ で確認さ れていることに加え，実際のイベント企画・実施状況にも現れて いるといえる。しかし屋内外の双方を活用したイベントは指定管 理者又は市の主催のみであり, 件数は各年度 5 件未満に留まる。 武蔵境エリアのまちづくり団体や近隣住民・事業主により開催さ れるイベントについては, 2013 年以降は毎年 20 件以上となって いる。また，公園のイベント利用件数は年々増加していることに 加え, 指定管理者や行政以外の主催者が増え多様化していること が確認された。なお，公園で撮影やイベント等を行う場合には指 定管理者への事前申請が必要である。武蔵野市立公園条例におい ては公園占用料金が設定されているが，面積が狭いため一般の利 用者を考慮し占用が発生しないよう撮影等の申請者と指定管理者 が調整している実態 36)があり，市の方針によりイベントについて は公益性のあるもののみ許可となるため占用料は発生せず無料で 空間が提供されている。

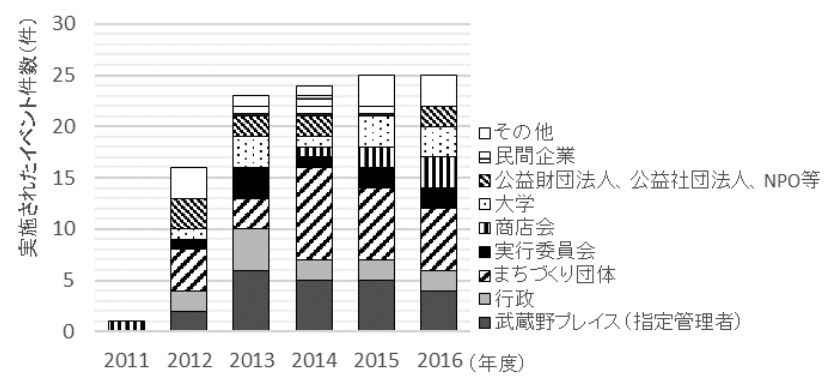

図－３＼cjkstart公園のイベント利用件数の推移

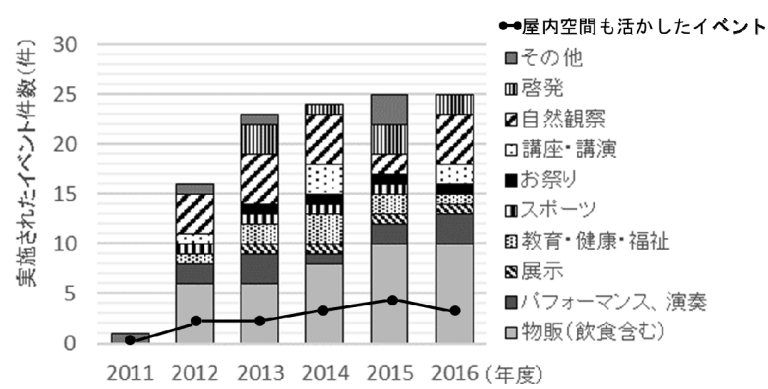

図-4 公園のイベント内容の推移 


\section{（2）定着したイベントに関するマネジメントの実態}

公園で行われるイベントのうち最も開催回数が多く定例化して いるものは「さかいマルシェ (以下，マルシェと記載)」である。 活性化委員会の主催であり, 武蔵野プレイス及び公園のオープン 1 年後の 2012 年 8 月に第 1 回が開催されて以降，毎年 4 月から 10 月（2014 年までは 11 月）の期間に月 1 回開催されている。内 容の構成としては，近隣の飲食店や物販店等の事業者，指定管理 者，市の環境政策課等による出店と，パフォーマンスが行われる ステージである。公園ができる前は類似イベントは周辺地域では 行われておらず，活性化委員会の発案による企画開始当初からこ の公園で行うことを前提に検討が進められ実現に至っている。 2017 年 9 月現在まで延べ 33 回開催されているが，その間におけ る開催時間帯や公園の空間の使い方等の变遷を整理した。開催時 間帯については，図書館機能を持った武蔵野プレイスに隣接する 公園での開催のため音環境への配慮がなされ，第 1 回から第 15 回までは武蔵野プレイスの開館時間前である午前 8 時から 9 時 30 分までの 1.5 時間で行われていた。しかし他のイベントの実施状 況も踏まえ開館時間帯に公園でイベントを開催していても武蔵野 プレイスの運用に大きな支障が出ないことが確認されたことに加 え，マルシェへの集客性向上を目的に，2015 年 4 月以降は午前 9 時から 11 時までの開催に変更され, 開催時間も 2 時間に延びた。

空間の使い方としては公園中央にある円形の芝生広場を取り囲 む形の店舗配置が当初から行われているが，ステージの位置は集 客を考慮し現在までの間に 2 度変更されている。出店数について は初年度 10 店舗程度だったが，2015 年に 20 店舗にまで増加し た。先述の芝生を囲む円形レイアウトを基本とし公園周囲の歩道 からの動線確保の必要があるため, 出店数の上限は 20 程度とな る。芝生広場にはテーブルとイスを配置し来場者は自由に飲食や ステージのパフォーマンス鑑賞が可能となっている（図一5）。マ ルシェ運営については近隣に立地する亜細亜大学の学生が演習の 一環として携わる試みが 2016，2017 年に実施され多様な主体と 連携した運営の取組みが確認された。運営に係る事業費について は1店舗あたり 1,000 円の出店料を徴収しており，これにより主 催者側の費用負担を軽減，マルシェの継続性を担保すると共に，

他のイベントの活動資金としても使用されていることを把握した。

\section{（3）活動と空間の特徵を踏まえた維持管理及び整備}

公園では通年の多様なイベント開催に加え，平日は武蔵境駅へ の通り抜けや子供の遊び空間として活発に利用され，保育園等の 園庭代わりとしての利用も確認された。これらの活動が芝生へ与 える影響は大きく, 特にイベント後には来場者の踏付けにより芝 生が剥がれ土が露出するため, 芝生回復の養生で広場が使用でき ない期間が頻繁に発生し, 利用者からは広場が使用できないこと への不満や芝生回復に係る費用を眯念する声が挙がっている。イ ベント利用が活発化した当初は芝生養生で広場が使用できず計画 していたイベントが中止されるという事象も発生していたが,

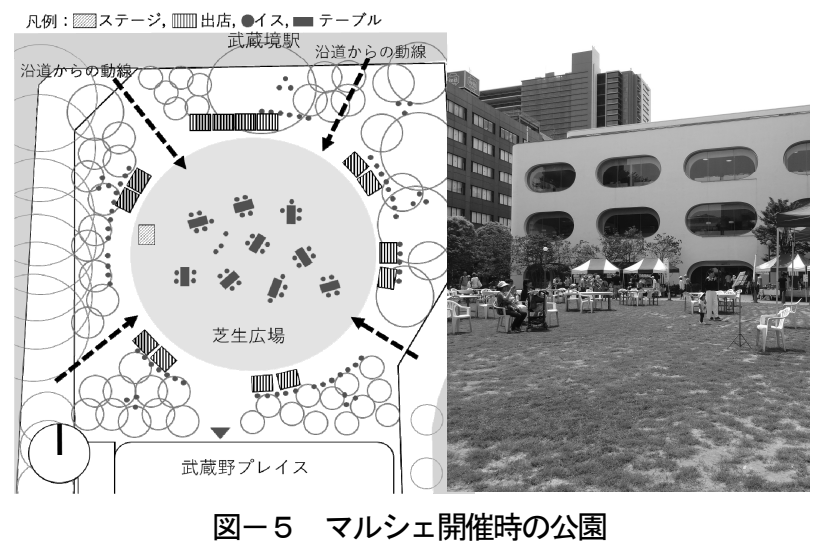

現在は主催者側・指定管理者側の情報共有によりイベント実施時 期と芝生養生の工程調整が図られ，重複無く運営されている。

活発な公園利用が芝生にダメージを与えていることは，市及び 指定管理者も課題として認識している。公園の指定管理料につい ても，芝生の維持管理費が主な要因となり毎年増額されている 36 ) この状況を踏まえ市の緑のまち推進課による企画・主導で芝生植 付けイベントが 2017 年 6 月に初めて開催された。イベントに係 る費用や準備及び実施に係る稼働は市が負担し，指定管理者は当 日の運営サポートという役割分担により行われた。このイベント の前月には地元の青年会議所主催のイベントが公園で行われ, 芝 生への影響が懸念されていた。この芝生復旧をイベント化し，青 年会議所のメンバーだけでなく一般市民の参加を募ることによっ て, 親子連れを中心とした延 123 名が参加して芝生植付けを行っ た ${ }^{34)}$ 。単なる復旧作業からイベントへと変えることで多くの参加 者が集まり，芝生自体や公園に対する親しみを醸成するだけでな く, 植付け前に市の職員による芝生の育成に関寸る解説が行われ, 参加者の理解促進にも寄与することを意図した取り組みであった。 公共空間に関する文献 14)37)を基に, 公共施設の屋外空間が担う ベき $5 つ の$ 活動のタイプの観点から, 必要となる空間要素を挙げ, 現状の公園におけるそれらの整備状況や空間の特徴及び公園で実 際に発生している活動について整理した（表一4）。公園の設計は 武蔵野プレイスの設計者によるものであり, 平常時から武蔵野プ レイスと連携した活動が行えるよう配慮され，竣工後特に空間の 構成や活動に影響するような整備・改修の履歴は無い。観察調査 の結果, 任意活動としては読書や勉強, 武蔵野プレイス利用の合 間の飲食を伴う休憩等が確認された。社会活動としては武蔵野プ レイス来館者の待合わせや偶然居合わせた子供同士の遊び，イベ ント参加者同士のコミュニケーション等の多彩な活動が見られた。

\section{5. 都市公園と公共施設の利活用を促進するマネジメントとそれ を実践する空間の在り方}

武蔵野プレイス及び公園の調査を踏まえ，隣接する公共施設と 都市公園の, 連携した利活用を促進するマネジメントとそれを実 践する空間の在り方に関寸る考察を行った。

\section{（1）連携に関する計画段階からの明確な位置づけ}

武蔵野プレイス及び公園に関しては, 計画段階の基本計画等で 空間の利用やマネジメントにおいて連携するということが明確に 位置づけられており，その内容は具体的な空間の構成に関するも の，利用形態・機能に関寸るもの，更には周辺のまちへの影響に 関するもの等多岐にわたっており，それらは文章で表されるだけ

\section{表-4 公共施設の屋外空間が担う活動と空間要素}

\begin{tabular}{|c|c|c|c|}
\hline $\begin{array}{l}\text { 活動の } \\
\text { タイプ }\end{array}$ & 必要となる空間要素 & $\begin{array}{l}\text { 現状の整備状況・・ } \\
\text { 空間の特改 }\end{array}$ & 発生している活動 \\
\hline $\begin{array}{l}\text { 必要 } \\
\text { 活動 }\end{array}$ & 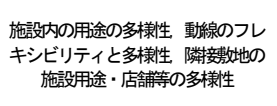 & 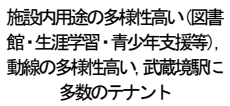 & 通り拢け，飲食 \\
\hline $\begin{array}{l}\text { 任意 } \\
\text { 活動 }\end{array}$ & 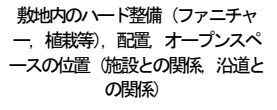 & $\begin{array}{c}\text { 多数のベンチとテーブル, 緑 } \\
\text { 陰, 施設と駅の間の公園 全方 } \\
\text { 向の沿道からアクセ可能な } \\
\text { デサイン, 中央の芝生広場 }\end{array}$ & $\begin{array}{l}\text { 飲食, 休䏡 読書, 楽器· } \\
\text { 歌練習, 仕事·勉強, か } \\
\text { けっこ, バトミントン等 } \\
\text { の軽し 運動 }\end{array}$ \\
\hline $\begin{array}{l}\text { 社会 } \\
\text { 活動 }\end{array}$ & 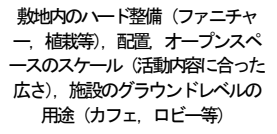 & 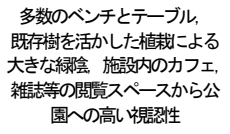 & $\begin{array}{l}\text { 待合せ, 偶然居合わせた } \\
\text { 子供同士の遊ひ、, 取材協 } \\
\text { カ, イベント参加者同士 } \\
\text { の交流 親同士の交流 } \\
\text { フリーペーパの撮影 }\end{array}$ \\
\hline 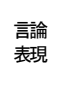 & $\begin{array}{l}\text { パフォーマンス・ } \\
\text { デモの開猚可能な広場 }\end{array}$ & $\begin{array}{c}\text { ステージ設置可能な広さ, 通行 } \\
\text { の妨けたなならず大人数力集合 } \\
\text { できる広場 }\end{array}$ & $\begin{array}{l}\text { ステージでのパフォー } \\
\text { マンス, デモの集合場所 }\end{array}$ \\
\hline $\begin{array}{c}\text { ハレの } \\
\text { 活動 }\end{array}$ & $\begin{array}{l}\text { 大型イベント，市場の開催可能な広 } \\
\text { 場、電原 光源 非常時 (防災) 用 } \\
\text { の設備（トイレ， かまど，水場等) }\end{array}$ & $\begin{array}{l}\text { 形の広場とその周囲の通路 } \\
\text { 発電機使用可能 トイレ, 水場 }\end{array}$ & $\begin{array}{l}\text { 多様なイベント } \\
\text { マルシェ }\end{array}$ \\
\hline
\end{tabular}


ではなく概念図やイメージパース等でも表現され，連携というこ とに関してより分かりや寸く伝えるものとなっていた。基本計画 に記載された連携に関する内容については，現在の指定管理者に よる管理運営においても意識的に取組まれていることから，上位 計画において連携について明確に位置づけを行い，その内容につ いて具体的に示すことに留意することが連携の実現のために重要 であると考えられる。

\section{（2）イベントと維持管理スケジュールの調整・整合}

イベント等による空間の利用が活発化すると，イベントのため の装置・設備の設置や来場者の活動により既存の設備・ファニチ ヤー・植栽の摩耗・損傷も増える。現在，公園においては空間活 用によりダメージを受けた芝生の養生期間と年間のイベントスケ ジュールの調整・整合が図られており，利用者への影響を少なく するための取組みが行われていた。また，維持管理費削減のため には効率化が重要ではあるものの，公園における芝生植付けイ心゙ ントは多くの市民の興味関心を引いたといえる。維持管理作業と イベントスケジュールの調整・整合により維持管理作業自体のイ ベント化が可能となり，効率化一辺倒ではなく，作業の意図や内 容を市民と共有化することで，公園と施設に対する市民の理解促 進や親しみ醸成につなげる有効な取組みになり得ると考えられる。

\section{（3）屋内外双方の空間特性の活用}

市や指定管理者主催のイベントにおいては，屋内外双方の空間 を管理し特徵を把握しているという利点から空間特性を十分に生 かした活用に取り組んでいることが確認された。しかし，公園で 行われるイベントの内容や開催主体の多様性が向上しているもの の，空間の活用は公園のみである場合がほとんどであり，武蔵野 プレイスの屋内への影響としては来場者のトイレ利用程度にとど まっている。音や臭い，利用者マナ一等における図書館等の機能 への悪影響が出ていないことは指定管理者及びイベント主催者の 努力や配慮によるものが大きいと考えられるが，公共施設と隣接 する公共空間という特徵を生かす活動として，屋内外双方の空間 特性の発揮に留意する必要がある。例えば，第 2 章で把握したよ うに平常時から屋内外双方の空間を生かした利用を促すマネジメ ントを行うことや, 第 3 章で把握した多様なイベント開催主体と 協議を行い屋内外の空間を生かしたイベント内容となるようにす ることで，更に公共空間としての魅力が向上寸ると考えられる。

\section{（4）イベント時以外の平常時における多主体の活動の連携}

本稿では, 武蔵野プレイス及び公園の指定管理者と活性化委員 会の間にはイベント以外も含めた双方向の連携体制が構築されて いることを把握した。この活性化委員会では地元の多様な民間事 業者や大学職員, 学生等が活動しており, その内容は公園でのイ ベント開催以外にもフリーペーパーの発行等多岐にわたる。この ように多主体との連携のコアになるような主体との間でイベント 時以外の平常時においても業務委託や情報共有等の様々な関わり 方を通した連携の継続に留意することが，活発で円滑なマネジメ ントや地域における公共空間の価值向上に寄与すると考えられる。

\section{（5）マネジメントに寄与するイベントの実施}

市の条例において公園占用料が設定されているが，現在は市及 び指定管理者による調整の結果，無料でスペースが提供されてい る。主催者側の費用負担が無いことからイベント開催の門戸を広 げ空間の利活用促進に寄与すると考えられるが，一方で指定管理 者が公園を「稼ぐ公共空間」として活用することに留意すると， 自主事業による収益確保や，得た収益を空間の質向上や市民サー ビス向上のための資金として還元することも可能となる。また, 利用者のマンパワー活用と空間への愛着の醸成につながるような 活動の重要性に留意し, マネジメント手法の一つとて継続する ことが施設や公園だけでなくまちへの愛着にも繋がり，施設のマ ネジメントからエリアのマネジメントにも発展すると考えられる。

\section{（6）今後の課題と展望}

今回の調査で確認された活発な利活用と多主体の連携について は，駅前の中心市街地における一事例として整理できる。今後は 立地適正化や公共施設の適正なマネジメント推進の動きから, 中 心市街地一の公共施設集約，低未利用地の活用，官民多主体の連 携がこれまで以上に求められることを見据え，このような中心市 街地における公共施設及び公園を連携させてマネジメントしてい く手法の確立に向けて類似事例分析の積み上げが求められる。

謝辞: 本研究を進めるにあたり，(公財) 武蔵野生涯学習振興事業 団，武蔵野市環境部緑のまち推進課，同財務部施設課，武蔵境活 性化委員会, (株) R 中央ラインモール業務推進本部, パブリック・ スペース(株)の皆様にご協力頂きました。厚く御礼申し上げます。

\section{補注及び引用文献}

1）国土交通省（2016）:「新たな時代の都市マネジメントに対応した都市公園等のあり 方検討会」最終とりまとめ

2）国土交通省（2016）: 都市公園のストック効果向上に向けた手引き，pp20 3）武蔵野市（1997）: 武蔵野市議会農水省跡地利用計画検討特別委員会報告書 4) 武蔵野市 (2001) : 新公共施設基本計画策定委員会 これまでの議論まとめ 5）武蔵野市（2002）: 新公共施設基本計画策定委員会報告書

6）武蔵野市 (2004): 農水省跡地利用施設建設基本計画策定委員会最終報告書

7) 武蔵野市 (2006-2008) : 武蔵野プレイス (仮称) 専門家会議 議事録

8）武蔵野市 (2006) : 武蔵野プレイス (仮称) 専門家会議報告書

9）武蔵野市 (2008) : 武蔵野プレイス（仮称）管理運営基本方針

10) 武蔵野市 (2005) : (仮称) 武蔵野プレイス基本設計概要版

11）武蔵野市 (2007) : (仮称) 武蔵野プレイス基本設計修正版

12）武蔵境活性化委員会 : フリーペーパー iisakai vol.1,2,3,8,9,10,11,15,21

13）(公財)武蔵野生涯学習振興事業団 (2011-2016) : 武蔵野プレイス年報

14）三浦詩乃・出口敦 (2014) : 旭川市平和通買物公園のマネジメントの変遷に関する 研究 : 日本建築学会計画系論文集第 79 巻第 696 号, 405-413

15）三浦詩乃・出口敦 (2015) : 旭川市平和通買物公園の利活用とマネジメントに関す 研究 : 日本建築学会計画系論文集第 80 巻第 713 号, 1635-1643

16）小篠隆生・小松尚・鶴㥓直樹 (2012) : 大学周辺地区における地域まちづくり主体 と大学の連携による空間マネジメントフィラデルフィア市, UCD とペンシルバニ ア大学を事例として：日本建築学会計画系論文集第 77 巻第 679 号, $2127-2136$

17）武田史郎 (2017) : キャンパスと公園がつくるまちのファブリック : ランドスケー プ研究 $81(2), 133-135$

18）恒川和久・柴田美里・太幡英亮・村上心・川野紀江・納村信之・松岡利昌 (2015) : 公共施設におけるアクティビティの分析と考察 : 日本建築学会計画系論文集第 80 巻 717 号, $2617-2624$

19）览玉澾朗・定行まり子・二輪律江（2013）：ファシリティマネジメントからみた地 域活動拠点としての小学校の使われ方 : 日本建築学会学術講演梗概集 (2013), 177-178

20）橋本直子・堤洋樹・水出有紀・池澤龍三 (2015) : 公共施設等総合管理計画におけ る土地の利用に関する研究 : 日本建築学会学術講演梗概集 (2015), 23-24

21）日本建築士事務所協会連合会 (2016) : 日事連Vol.54 No.9, pp12-15

22) 佐藤嵩・大平渉・渡边富雄 (2012) : 武蔵野プレイスの利用タイプと行為につい: 日本建築学会学術講演梗概集 (2012), 293-294

23）(株ビルネット (2012) : 指定管理者制度 No.74，pp18-29

24) (公社) 日本ファシリティマネジメント協会 (2017) : JFMA ジャーナル No.187, pp30-33

25）地理院地図（電子国土Web）を引用し筆者が加筆

26) 東京都武蔵野市 (2014) : 社会資本総合整備計画 武蔵境駅周辺地区都市再生整備 計画を基に作成

27）邑上氏が武蔵野プレイス規模縮小を公約の一つに掲げ 2005 年市長に初当選した 28) 2015 年 6 月 11 日実施の(公財)武蔵野生涯学習振興事業讨への聞取り調查に基づく 29） 2017 年 8 月実施の JR 中央ラインモール業務推倠本部への質問紙調査に基づく

30)東日本旅客鉄道株式会社八王子支社ホームページ，プレスリリース

https://www.jreast.co.jp/hachioji/info/20170309/20170309_info3.pdf (2017年 3 月 9 日更新, 2017 年 9 月 10 日参照)

31）武蔵野市市民部 (2013) : 武蔵野市産業振興基礎調査報告書来街者調査編 32）指定管理者制度 : 武蔵野市ホームページ

http://www.city.musashino.lg.jp/shisei_joho/sesaku_keikaku/kikakuseisakushitsu/ shiteikanrishaseido/ $1007835 . h t m l$ (2017 年 4 月 7 日更新, 2017 年 9 月 10 日参照) 33) 2016 年 10 月 7 日実施の(公財)武蔵野生涯学習振興事業団への聞取り調査に基づく 34) 2017 年 6 月 21 日実施の武蔵野市環境部緑のまち推進課への聞取り調査に基づく 35）むさしさかいの「人」を伝えるフリーペーパー「iiisakaiいいさかい」 36) 2017 年 9 月 21 日武蔵野市環境部緑のまち推僬課からのメール回答による 37) ヤン・ゲール(2011) : 建物のあいだのアクティビティ: 鹿島出版会 